\title{
KONSTRUKSI FIQH BUKHARI DALAM KITAB AL-JAMI' AL-SHAHIH
}

\author{
Abdul Sattar \\ Fakultas Dakwah IAIN Walisongo Semarang \\ Email:abdsattar@yahoo.com
}

\begin{abstract}
Abstrak
The popularity of Imam Bukhari as compiler of sunnah has an outstanding position among Muslim communities in the world. His work al-Jami' al-Shahih regarded as the best sunnah collection after the Quran. However, there is not enough information about his capability on Islamic Law (figh). The are many questions can be offered to this case. First, is Imam Bukhari's thought under the influence one of four Sunnites fuqaha when he was writing al-Jami' al-Shahih?. Second, what does he do to articulate his thought on Islamic law?. Using explorative, verified and hermeneutical approaches, this article will show us that Imam Bukhari is not under the influence of any particular schoosl of thought in articulating his thought on Islamic law. He articulated his point of view in unique and excellent ways based on his capacity as muhaddits.

Popularitas Imam Bukhari sebagai penyusun kitab Hadits memiliki posisi yang tinggi di kalangan masyarakat muslim. Kitab Al-Jami 'al-Shahih karya Imam Bukhari dianggap sebagai koleksi hadits terbaik setelah Quran. Namun, tidak ada banyak informasi tentang kemampuannya di bidang Hukum Islam (figh). Ada beberapa pertanyaan yang dapat diajukan dalam hal tersebut; pertama, apakah pemikiran Imam Bukhari dipengaruh salah satu dari empat fuqaha Sunni saat menulis al-Jami 'al-Shahih?. Kedua, apa yang diupayakan Imam Bukhari untuk mengartikulasikan pemikirannya tentang hukum Islam? Dengan menggunakan pendekatan eksploratif, verifikatif dan hermenetical, artikel ini akan mengungkapkan bahwa Imam Bukhari tidak berada di bawah pengaruh madhab tertentu dalam mengartikulasikan pemikirannya tentang hukum Islam. Dia mengartikulasikan pandangannya dengan cara yang unik dan execelent berdasarkan kapasitasnya sebagai muhaddits.
\end{abstract}

Kata Kunci: Imam Bukhari, fiqh and al-Jami' al-Shahih

Sosok Imam Bukhari (194-256 H) lebih dikenal sebagai ahli hadits ketimbang ahli fiqh. Hal ini dapat dimaklumi karena dari sekian banyak karya Imam Bukhari, al-Jami' al-Shahih atau yang sering disebut Shahih Bukhari, merupakan karyanya yang paling spektakuler. Bahkan karya ini dipandang sebagai kitab hadits paling otentik setelah al-Quran. ${ }^{1}$ Pendapat ini dikemukakan dan

1 Jalal a-Din al-Suyuthi, Tadrib al-Rawi, ed. Abd al-Wahab 'Abd al-Latif (Madinah: al-Maktabah dipopulerkan oleh Imam Nawawi (w.676 H) seraya memberikan tambahan bahwa para ulama telah sepakat (ijma') dalam masalah ini. ${ }^{2}$

Pernyataan al-Nawawi tidaklah berlebihan sebab dalam menyusun kitabnya, Imam Bukhari telah menetapkan syaratsyarat yang sangat ketat. Pertama, perawi al-`Ilmiah, 1392 H), h. 91.

2 Al-Nawawi, Syarh Muslim (Jilid I ; Beirut: Dar al-Fikr, 1402 Hit h. 14. 
haruslah seorang muslim yang berakal, adil, kuat hafalan (dabith), tidak melakukan manipulasihadits (tadlis), selalu memelihara apa yang diriwayatkannya, sehat pikiran dan panca indera, sedikit melakukan kesalahan dan beriktikad baik. Kedua, sanadnya harus bersambung, sehingga hadits mursal, munqathi' dan mu'dal tidak masuk dalam kualifikasi hadits yang dia tulis. Ketiga, matan hadits tidak janggal (syadz) dan tidak mengandung cacat (mu'allal). ${ }^{3}$

\section{Sahih Bukhari: Leverage Popularitas Imam Bukhari}

Imam Bukhari adalah seorang ulama yang sangat produktif dengan karya yang meliputi berbagai bidang keilmuan. Beberapa diantara karyanya antara lain: al-Tarikh alShaghir, al-Tarikh al-Kabir, al-Du'afa', alKuna, al-Adab al-Mufrad, Raf'u al-Yadain fi al-Shalah, Khair al-Kalam fi al-Qiraah Khalfa al-Imam, al-Asyribah, Asami al-Shahabah, Bir al-Walidain, Khalq Af'al al-'Ibad, al-'Ilal fi alHadits, al-Musnad al-Kabir, al-Wuhdan, alMabsuth, al-Hibah serta al-Jami' al-Shahih. Dari judul-judul ini terlihat bahwa dia tidak hanya ahli hadits, tetapi juga seorang sejarawan, teolog dan ahli fiqh.

Sebagian kitab-kitab tersebut, dari sudah dicetak dan sebagian lagi berupa manuskrip, serta ada pula yang hanya diketahui melalui kutipan sebagian ulama. ${ }^{4}$ Meskipun menulis beberapa kitab dengan tema yang cukup variatif, Imam Bukhari terkenal karena kitabnya yang berjudul alJami' al-Musnad al-Shahih al-Mukhtashar min Umur Rasulillah wa Sunanihi wa Ayyamihi yang kemudian lazim dikenal dengan sebutan al-Jami' al-Shahih atau Shahih Bukhari. ${ }^{5}$ Dengan kata lain, seandainya tidak melahirkan kitab ini, barangkali Imam Bukhari tidak akan sehebat sekarang.

Ada dua faktor yang mendorong Imam

3 Muhammad Muhammad Abu Syuhbah (selanjutnya disebut Abu Syuhbah), Fi Rihab alSunnah al-Kutub al-Shihah al-Sittah (Kairo: Majma' alBuhuts al-Islamiah, 1979), h. 62.

4 Ibnu Hajar, Muqaddimah Fath al-Bari (Jilid II; Beirut: Dar al-Fikr, t.t), h. 204.

5 Nur al-Din 'Ithr, Manhaj al-Naqd fi 'Ulum alHadits (Beirut: Dar al-Fikr, 1401 H), h. 253.
Bukhari menyusun kitabnya yang spektakuler itu. Pertama, jauh sebelum Imam Bukhari menyusun kitabnya, telah banyak ulama hadits yang berusaha membukukan hadits-hadits Nabi dalam satu kitab tersendiri. Tokoh-tokoh seperti al-Rabi' ibn Shabih (w. 160 H), Sa'id ibn Abu 'Arubah (w. 156 H), Imam Malik ibn Anas dengan karyanya al-Muwattha' di Madinah, Ibnu Juraij di Makkah dan al-Auza'i di Basrah. Hanya saja kitab-kitab hadits itu masih bercampur dengan fatwa-fatwa sahabat, tabi'in dan tabi'it tabi'in. Pada masa berikutnya (awal abad II) para ulama telah berusaha untuk membukukan hadits Nabi secara tersendiri; artinya tidak tercampur dengan fatwa-fatwa sahabat dan tabi'in. Maka muncullah tokoh-tokoh Nu'aim alKhuza'i, 'Ubaidillah al-Kufi, Musaddal alBishri dan Asad al-Umawi, yang kemudian diikuti oleh Imam Ahmad ibn Hanbal, Ishaq bib Rahawaih, Utsman ibn Abi Syaibah dan lain-lain. namun, karya-karya tersebut tidak membedakan hadits-hadits yang shahih, hasan dan da'if. Dari sini kemudian Imam Bukhari punya inisiatif mengumpulkan hadits-hadits yang shahih saja. ${ }^{6}$ Ishaq Rahawaih guru al-Bukhari, mendorong maksud itu, seperti dituturkan oleh Imam Bukhari: "Ketika aku berada di depan Ishaq ibn Rahawaih, dia berujar: 'Alangkah baiknya jika kamu menyusun sebuah kitab yang khusus menghimpun sunnah Rasulullah Saw yang shahih saja'. Lebih lanjut Imam Bukhari menambahkan: "Maka, tertanamlah anjuran itu di dalam hatiku. Lalu aku mulai menghimpun kitab al-Jami' al-Shahih". ${ }^{\prime}$

Kedua, tekadnya untuk menyusun kitab al-Jami' al-Shahih semakin kuat karena terdorong oleh mimpinya al-Bukhari menuturkan: "Aku bermimpi melihat Nabi Saw. Seolah-olah aku berdiri di hadapannya

6 Perlu dicatat bahwa suatu ketika Imam Bukhari pernah berkata: "Saya hafal 100 ribu buah hadits shahih, tetapi saya juga hafal 200 ribu diluar hadits shahih. Lihat al-Dzahabi, Tadzkirah al-Huffadh (Juz II; Beirut: Dar al-Kutub al-'Ilmiah, t.t), h. 556.

7 Ibnu Hajar, Hadi al-Sari (Jilid I ; Riyad: Risalah Idarat al-Buhuts al-'Ilmiah wa al-Ifta' wa alDa'waltwa tal-Irsyad, t.t), h. 6-7. 
seraya mengipasi dia. Setelah itu aku tanyakan mimpi itu kepada seorang ahli ta'bir mimpi. Ia menjelaskan bahwa aku akan menghancurkan dan mengikis habis kebohongan dari hadits Rasulullah Saw. Mimpi ini telah mendorongku untuk menulis kitab al-Jami' al-Shahih. ${ }^{8}$

Kedua hal itulah antara lain yang membuat Imam Bukhari termotivasi untuk membukukan hadits-hadits shahih dalam satu kitab khusus. Menurut Ibnu Shalah dan Imam Nawawi, kitab Shahih Bukhari berisi 7.275 hadits, termasuk hadits-hadits yang diulang. Apabila tanpa pengulangan, jumlahnya hanya sekitar 4.000 buah hadits dari 600.000 hadits yang diperoleh dari 1.000 guru. Koleksi Shahih Bukhari ditulis dalam masa 16 tahun; berisi lebih dari 100 judul bab dan 3.450 sub bab. Lamanya penulisan itu disebabkan karena Imam Bukhari sangat cermat dalam menyeleksi hadits. Bahkan dia tidak mau menulis satu hadits pun sebelum dia mandi lalu shalat dua rakaat dan yakin bahwa hadits yang ditulisnya itu benar-benar shahih. ${ }^{9}$

Apa yang dilakukan oleh Imam Bukhari bukan berarti tanpa kritik sebagian ulama hadits lain. Al-Daruquthni misalnya mengkritik sejumlah hadits dalam Shahih Bukhari karena dinilai tidak memenuhi persyaratan peringkat tinggi (al-darajah al-'aliyah) seperti yang ditetapkan oleh Imam Bukhari. Namun hal itu tidak berarti hadits-hadits yang dikritik tersebut sangat lemah (da'if) yang sampai pada batas maudu' atau mungkar. Sebab, menurut Abu Syuhbah, tidak seorang pun ulama yang berpendapat demi-

8 Ibnu Hajar, Hadi., 7 (Lihat juga Abu al-Falah 'Abd al-Hay, Syadzrat al-Dzahab fi Akhbar man Dzahab (Juz II ; Beirut: Dar al-Kutub al-'Ilmiah, t.t), h. 134.)

Sebab Imam Bukhari juga pernah mengatakan: "Saya tidak memasukkan ke dalam kitab Shahih Bukhari selain hadits yang benar-benar shahih. Tetapi saya juga banyak sekali meninggalkan hadits shahih karena terlalu panjang. Lihat Ibnu Hajar, Tahdzib., h. 40.

9 Sebab Imam Bukhari juga pernah mengatakan: "Saya tidak memasukkan ke dalam kitab Shahih Bukhari selain hadits yang benar-benar shahih. Tetapi saya juga banyak sekali meninggalkan hadits shahih karena terlalu panjang. Lihat Ibnu Hajar, Tahdzib., h. 40. kian. ${ }^{10}$

\section{Klaim Afiliasi Fiqh Imam Bukhari}

Sementara dalam kajian hadits Imam Bukhari menempati posisi istimewa karena ketatnya persaratan yang ia tentukan dalam menyeleksi hadits, bagaimana posisinya dalam fiqh? Persoalan ini menjadi menarik karena afiliasi fiqh Imam Bukhari masih diperdebatkan ulama. Hal ini bisa dimaklumi karena Imam Bukhari lahir setelah generasi para fuqaha besar seperti Imam Hanafi, Malik, Syafii dan Ahmad ibn Hanbal. Taqiyuddin Ibnu Qadi Syuhbah al-Dimasyqi (779-851 H) dalam kitabnya, Thabaqat al-Syafi'iah, memasukkannya sebagai pengikut Imam Syafii. Menurutnya, Imam Bukhari masuk thabaqat kedua karena dia tidak berguru langsung kepada Imam Syafii; dia hanya berguru pada murid-murid Imam Syafii seperti al-Humaidi, alZa'farani, al-Karabisi dan Abu Tsaur. ${ }^{11}$

Sementara itu, Ibnu Abi Ya'la (w.526 H) dalam kitabnya, Thabaqat al-Hanabilah, justru memasukkan Imam Bukhari dalam kelompok pengikut Ahmad ibn Hanbal. Bahkan untuk menegaskan pendapatnya, Ibnu Abi Ya'la mengetengahkan biografi Imam Bukhari dalam sembilan halaman tulisannya. ${ }^{12}$

Akan tetapi, ulama Malikiah juga memasukkan Imam Bukhari sebagai pengikut Imam Malik karena dia meriwayatkan alMuwattha' dari murid-murid Imam Malik seperti Sa'id ibn Anbar, Ibnu Bukair dan Abdullah ibn Yusuf. Bahkan dari tokoh yang disebut terakhir ini, Imam Bukhari

10 Seorang ahli hadits terkemuka, Ibnu Hajar al-'Asqalani, dalam pendahuluan kitab komentarnya tentang Shahih Bukhari, telah memberikan pembelaan terhadap hadits-hadits Shahih Bukhari yang dikritik tersebut secara global, kemudian secara detail. Ia paparkan hadits-hadits itu satu persatu dengan disertai kritik para kritikusnya kemudian setiap kritikan tersebut diberi bantahannya. Lebih detail lihat Ibnu Hajar, Muqaddimah., h. 83-110; Lihat juga Abu Syuhbah., h. 55.

11 Taqiyuddin Ibnu Qadi Syuhbah al-Dimasyqi (selanjutnya disebut al-Dimasyqi), Thabaqat alSyafi'iah (Juz I; Beirut: Dar al-Fikr, t.t), h. 83-84.

12 Ibnu Abi Ya'la, Thabaqat al-Hanabilah (Juz I; Beirut: Dacal-Ma'arifttt.t), h. 271-279. 
meriwayatkan hingga 236 hadits. ${ }^{13}$

Kelompok ulama Hanafiah juga tidak ketinggalan. Mereka menganggap Imam Bukhari pengikut Imam Hanafi. kerena guru yang menganjurkannya untuk menulis kitab Shahih Bukhari Ishaq ibn Rahawaih, salah seorang pengikut setia madzhab Hanafi, yang darinya Imam Bukhari banyak belajar dan meriwayatkan hadits. ${ }^{14}$

Dengan variasi klaim sedemikian rupa, maka pertanyaan yang relevan adalah apakah ketika menyusun kitabnya Imam Bukhari benar-benar memperhatikan aturan main yang berlaku dalam ilmu hadits? Atau apakah "afiliasi" madzhab fiqhnya benarbenar mempengaruhi pemilikan hadits dalam kitabnya?

Sekedar illustrasi, ada kasus menarik berkenaan dengan cara tayammum. Imam Bukhari tidak meriwayatkan dua hadits yang terdapat dalam al-Muwattha' Imam Malik. Padahal jalur dari kedua hadits tersebut, menurut Imam Bukhari, masuk dalam kategori "mata rantai emas" (silsilah al-dzahab) karena diriwayatkan secara berurutan oleh Malik-Nafi'-'Abdullah Ibnu 'Umar. Namun Imam Bukhari justru menampilkan empat riwayat 'Ammar ibn Yasir. ${ }^{15}$ Pertanyaannya adalah apa maksud Imam Bukhari menafikan dua jalur silsilah al-dzahab itu? Sementara pada kasus yang sama, dia menampilkan empat riwayat lain yang isi haditsnya "kebetulan" sejalan dengan pandangan Imam Syafii yang menjelaskan bahwa muka dan telapak tangan hingga siku harus diusap ${ }^{16}$

Jika misalnya terbukti bahwa ketika menyeleksi hadits, Imam Bukhari terpengaruh

13 Al-Husaini 'Abd al-Majid Hasyim (selanjutnya disebut al-Husaini), al-Imam al-Bukhari: Muhaddits wa Faqih (Kairo: Dar al-Qaumiah li alThiba'ah wa al-Nasyr, 1996), h. 167; Ibnu Hajar, Tahdzib., h. 80.

14 Al-Husaini, al-Imam., h. 167.

15 Ibnu Hajar, Tahdzib., Juz X, h. 5-8; Imam Bukhari, al-Jami' al-Shahih (Indonesia: Dar Ihya alKutub al-'Arabiyah, t.t), Juz I, h.71 \& 73; Imam Malik, al-Muwattha' (Beirut: Dar Ihya al-`Ulum, 1990), h. 57.

16 Imam Syafii, al-Umm (Juz I ; Beirut: Dar al-Fikr, 1983), h. 41; lihat juga Imam Syafii, Ikhtilaf al-Hadits (Beirut: Muassasah al-Kutub al-Tsaqafiah, 1985), h. 95-97.
dengancorakfiqhSyafii, makawajarbilaIbnu Shalah dan al-Nawawi ${ }^{17}$ seperti yang sudah disebutkan dalam pendahuluan tulisan ini dari kalangan ulama Syafi'iyah melakukan pembelaan terhadap kitab al-Jami' al-Shahih dan menganggap penulisannya sebagai bagian dari kelompoknya. Fenomena seperti ini merupakan kewajaran psikologis yang sepenuhnya bisa dimengerti.

\section{Pemetaan Pandangan Fiqh Imam Bukhari}

Banyak sekali karya yang ditulis berkenaan dengan kapasitas Imam Bukhari sebagai ahli hadits, tetapi tidak cukup banyak informasi yang dapat diperoleh berkenaan dengan pandangan fiqhnya, sebab hampir semua tulisan yang membicarkan Imam Bukhari hanya sekedar memberikan informasi yang masih mentah. Ibn Hajar misalnya, hanya mencantumkan pernyataan Hasyid ibn Ismail sebagai berikut: "Saya tinggal di Basrah.KetikaMuhammadibnIsmail(Imam Bukhari) datang ke Basrah, Muhammad ibn Basyar berkata: "Pada hari ini telah datang pemimpin para fuqaha (sayyid al-fuqaha)" ${ }^{18}$ Pernyataan ini tidak cukup meyakinkan untuk mengukuhkan status Imam Bukhari sebagai seorang faqih.

Carl Brockelmann dalam Encyclopedia of Islam sedikit lebih jelas ketika menyatakan: "His collection on tradition al-Djami' al-Sahih established his reputation. This work is divided according to the chapters of figh". ${ }^{19}$ Informasi ini hanya sebatas identifikasi mengenai karakter penulisan al-Jami' al-Shahih.

Kemudian dalam The Encyclopedia of Islam, J.Robson menambahkan: "Although al-Subki includes al-Bukhari among the Shafii Faqihs, this is not accurate, for he did not hold consistently the doctrine of any particular school". ${ }^{20}$ Informasi inipun belum me-

17 Abd al-Rahim al-Asnawi, Thabaqatal-Syafiiah (Juz II ; Beirut: Dar al-Kutub al-'Ilmiah, 1987), h. 41 \& 266-267.

18 Ibnu Hajar, Tahdzib., h. 41.

19 Carl Brockelmann, E.J Brill's Encyclopedia of Islam 1913-1936, ed. M.Th.Houstma et.all (Vol. II; Leiden: E.J Brill, 1987), h. 783.

20 J.Robson, The Encyclopedia of Islam, ed. H.A.R Gibb et.all (Vol.I; Leiden: E.J Brill, 1960), h. 1297; lihat juga H.A.R Gibb dan J.H Kramers, Shorter Encyclopedat of Islith (Leiden: E.J Brill, 1961), h. 65. 
nunjukkan identitas fiqh Imam Bukhari, sebab jika Imam Bukhari tidak konsisten berpegang pada madzhab tertentu, lantas seperti apa konstruk fiqhnya ?

R. Marston Speight memberikan gambaran yang lebih jelas. Ketika menulis aljami' al-shahih, dia menyatakan: "It was intended to be a tool for study of jurisprudence, with many of the texts arranged according to the categories of Islamic law; the heading of the different sections reveals the compiler's competence in jurisprudence. Although all four schools of sunni law consider him to be one of their basic sources, he never identified with any particular school". ${ }^{21}$

Pernyataan R. Marston Speight tersebut semakin jelas setelah melihat komentar Abu Syuhbah yang menegaskan bahwa: “Tujuan utama dan paling mendasar dari para pengumpul dan penghafal hadits adalah mengumpulkan sunnah Rasulullah dan memeliharanya agar tidak hilang; bukan untuk merumuskan dan menggali hukum, sebab itu adalah tugas ulama fiqh. Meskipun demikian, Imam Bukhari banyak mengemukakan masalah-masalah penting berkenaan dengan masalah fiqh dan adab. Dengan ketajaman otaknya, ia menggali masalah-masalah tersebut darimatan hadits yang dicantumkan secara tersebar dalam berbagai bab dalam kitabnya. Demikian pula ia mencantumkan ayat-ayat al-Quran berkenaan dengan masalah fiqh dan bab yang sedang dibahas serta mencantumkan pula penafsiran ayat-ayat yang diterimanya dari ulama sebelumnya. Kefaqihan Imam Bukhari nampak dalam hal mengutarakan sebagian masalah yang dikemukakan secara tidak pasti jika dalam masalah tersebut terdapat perbedaan, dan tidak ada pendapat yang menurutnya lebih kuat. Misalnya "Bab apakah masalahnya demikian". Demikian pula corak fiqhnya itu tampak dalam usahanya menyebutkan pendapatpendapat sahabat atau tabiin yang menjadi dalil atau penguat bagi satu pendapat atas

21 R. Marston Speight, The Encyclopedia of Religion, ed. Micea Eliade (Vol. II; London: Collier Macmillan Publishers, 1993), h. 53. pendapat yang lain. Juga tampak dalam catatan-catatan yang ditulisnya sebagai komentar atas suatu hadits. Misalnya saat dia sendiri mengatakan: "Abu Abdullah (yakni Imam Bukhari) berkata: 'begini dan begitu' . Tetapi corak fiqhnya yang menonjol terletak pada sistematika kitab dan isinya. Karena itulah ada yang mengatakan: "Corak fiqh Bukhari terletak pada judul bab dan sistematikanya". Menurut pendapat saya, tambah Abu Syuhbah, Imam Bukhari bukanlah pengikut madzhab tertentu. Dia mempunyai pendapat-pendapat hukum yang digalinya sendiri. Pendapat-pendapat itu terkadang sejalan dengan madzhab Abu Hanifah, terkadang sesuai dengan madzhab Syafii dan terkadang berbeda dari keduanya. Selain itu, pada suatu saat ia memilih madzhab Ibnu 'Abbas, dan di saat lain memilih madzhab Mujahid, 'Atha' serta yang lainnya. Jadi kesimpulannya, Imam Bukhari adalah seorang ahli hadits yang ulung dan ahli fiqh yang berijtihad sendiri, kendatipun yang paling menonjol adalah kapasitasnya sebagai ahli hadits, bukan ahli fiqh".

Sejauh literatur yang telah disebutkan diatas, belum ditemukan bukti-bukti nyata yang menjadi indikator kuat bahwa Imam Bukhari adalah seorang faqih. Untuk melengkapi kekurangan ini, sebenarnya dalam Ensiklopedi Islam Indonesia telah dikemukakan contoh-contoh pendapat fiqh Imam Bukhari. Bahkan dengan sangat jelas dikemukakan bahwa Imam Bukhari juga terkenal sebagai ahli fiqh dan mujtahid. Diantara contoh pandangannya dalam fiqh adalah sebagai berikut; 1) Bertemunya dua alat kelamin (hubungan suami istri) tanpa ejakulasi tidak wajib mandi. 2) Sperma yang melekat di kain, boleh dibasuh dan boleh juga hanya dengan dikikis saja. 3) Bila hari raya jatuh pada hari Jum'at, orang yang telah shalat 'id tidak perlu lagi shalat jumat. 4) Sakit adalah salah satu udzur yang membuat orang boleh menjamak shalat. 5) Hadits da'if tidak bisa dijadikan dalil, baik dalam hukum maupun keutamaan amal

\section{Created with \\ (n) nitro $^{\text {PDF }^{\prime}}$ professional}


(fadail al-a'mal). ${ }^{22}$

Sangat disayangkan Ensiklopedi Islam Indonesia tidak mencantumkan penulis entri ke dalam daftar referensi pada tiap akhir tulisan. Hal ini berbeda dengan ensiklopedi terbitan luar negeri yang hampir selalu mencantumkan penulis entri dan referensi yang bisa dirujuk. Meskipun demikian, informasi tersebut tetap menarik untuk dielaborasi dengan asumsi bahwa penulisnya pasti mendasarkan tulisannya atas data-data yang valid.

Satu-satunya informasi yang cukup komprehensip membahas kefaqihan Imam Bukhari adalah karya Dr. al-Husaini 'Abd al-Majid Hasyim yang berjudul al-Imam al-Bukhari: Muhaddits wa Faqih. Dikatakan komprehensip karena penulisnya telah sampai pada kesimpulan bahwa Imam Bukhari adalah seorang faqih sekaligus mujtahid. Selain itu, dia juga mengemukakan contoh-contoh fiqh Bukhari sekaligus menganalisanya dalam 38 halaman (dari halaman 161-198).

Berikutakandikemukakanhal-hal pokok yang telah dicapai oleh al-Husaini. Beberapa diantaranyasama denganungkapan penulis lain seperti Carl Brockelmann, J.Robson dan H.A.R Gibb serta J.H Kramers. Pertama, isyarat fiqh Imam Bukhari dapat dilihat dari pencantuman pendapat-pendapat sahabat dan tabi'in serta bab-bab yang terdapat didalamnya. Kedua, Imam Bukhari tidak terikat pada madzhab tertentu. Ketiga, Imam Bukhari seorang mujtahid mutlak, bukan mujtahid madzhab. ${ }^{23}$

Untukmemperkuatkesimpulantersebut, al-Husaini mengemukakan beberapa bukti tentang fiqh Bukhari yang cukup menarik dan unik, antara lain; a) Mengusap kepala dalam wudu' hanya sekali, bukan tiga kali sebagaimana pendapat kelompok Syafiiah. b) Orang junub dan wanita menstruasi boleh membaca al-Quran. Pendapat ini sama dengan pendapat Ibn 'Abbas tetapi berbeda

22 Harun Nasution et.all (Tim Penyusun), Ensiklopedi Islam Indonesia (Jakarta: Djambatan, 1992), h. 182.

23 Al-Husaini, al-Imam., h. 165-166, 168-169, 173. dengan mayoritas fuqaha. c) Orang yang melakukan hubungan suami istri pada siang hari bulan Ramadan, wajib memba_ yar kafarat (denda) tetapi tidak wajib qada' (mengganti) puasa. Pandangan ini berbeda dengan pendapat Hanafiah, Syafiiah, Hanabilah dan Malikiah yang mewajibkan kafarat sekaligus qada'. d) Rikaz adalah barang-barang orang jahiliah yang telah terpendam. Adapun tambang (al-ma'dan) tidak termasuk rikaz. e) Kesaksian pencuri, pezina dan orang yang pernah menuduh orang lain berbuat zina ( $q a d z a f$ ) bisa diterima setelah mereka bertaubat. f) Zakat tidak gugur hanya karena hilah..$^{24}$ g) Pernikahan tidak batal hanya karena kesaksian palsu meskipun mempelai pria tahu betul bahwa kesaksian itu tidak benar. ${ }^{25}$

Dari gambaran tersebut, terlihat bahwa al-Husaini sampai pada kesimpulan yang meyakinkan akan status Imam Bukhari adalah seorang faqih. Namun perlu juga dicatat bahwa beberapa bukti yang dikemukakan al-Husaini terkadang kurang berimbang, misalnya tentang "mengusap kepala dalam wudu' hanya sekali", padahal Imam Bukhari juga menampilkan versi hadits lain yang menerangkan tata cara wudu' yang dilakukan dengan cara dua kali dan tiga kali. Versi hadits yang tidak disebutkan al-Husaini ini tertuang dalam bab yang oleh Imam Bukhari dimasukkan kedalam "bab al-wudu' marratain dan bab al-wudu' tsalatsu marrat". Selain itu, dalam mengkaji fiqh Bukhari, al-Husaini tidak sedikitpun menguji hadits yang termuat dalam al-Jami' al-Shahih. Misalnya al-Husaini tidak mempertanyakan mengapa Imam Bukhari mencantumkan sebuah versi hadits tertentu tetapi mengabaikan versi yang lain? Atas pertimbangan apa Imam

24 Hilah adalah rekayasa yang dilakukan orang yang mestinya wajib mengeluarkan zakat supaya tidak jadi mengeluarkan zakat. Misalnya, si A memiliki 30 ekor sapi. Supaya tidak kena zakat, sebelum jatuh tempo satu tahun satu ekor sapinya dijual sehingga jumlah sapi setelah jatuh tempo setahun pemeliharan tinggal 29 ekor. Tujuannya tiada lain supaya tidak masuk nisab karena jumlah sapi 29 ekor, bukan 30 ekor yang menjadi sayart nisab sapi.

25 credttHusaini, al-Imam., h. 188-197. 
Bukhari melakukan itu? Hal-hal inilah yang sebenarnya menarik untuk ditelaah. Oleh karena itu, untuk memetakan posisi Imam Bukhari, upaya mencermati pandangan empat tokoh fuqaha sunni sebelum Imam Bukhari adalah sebuah keniscayaan. Untuk melihat bagaimana konstruk fiqh Bukhari memang tidak mudah, apalagi memotret pandangan-pandangan atas dasar didasarkan pada kitab al-Jami' al-Shahih, sebuah kitab hadits yang pada awalnya tidak dimaksudkan untuk mengemukakan pandangan fiqh. Oleh karena itu, untuk memperoleh gambaran yang akurat, maka telaah exploratif, veirifikatif dan pembacaan hermeneutic harus dilakukan.

\section{Beberapa Pemikiran Hukum Imam Bukhari}

Dari telaah yang penulis lakukan, ada sekitar 16 kasus menarik yang bisa disajikan dan dianalisis berkenaan dengan hadits-hadits yang dikumpulkan oleh Imam Bukhari dalam kitab al-Jami' al-Shahih. Kasus-kasus tersebut adalah: cara membersihkan kencing bayi laki-laki, mengusap kepala dalam wudu', mencium istri dan menyentuh kemaluan, kewajiban mandi bagi mereka yang melakukan hubungan suami istri, mengambil debu untuk tayammum, mengusap tangan dalam tayammum, orang junub dan menstruasi boleh menyentuh al-Quran, doa setelah takbiratul ihram, bacaan basmalah dalam shalat, jumlah rakaat shalat tarawih (qiyam al-lail), doa qunut dalam shalat subuh, hubungan suami istri pada siang hari bulan Ramadan, zakat tidak gugur karena hilah, nikah mut'ah, menikahi wanita ahl al-kitab serta muslim-kafir tidak saling mewarisi. Dari beberapa kasus tersebut, ada 3 contoh yang akan dikemukakan dalam tulisan ini.

\section{Muslim - kafir tidak saling mewarisi}

Ketika membahas persoalan harta warisan, al-Syaibani ${ }^{26}$ menuliskan: "Kami se-

26 Al-Syaibani adalah murid Imam Hanafi yang paling terkenal; dan dari murid inilah rekamanrekaman pendapat Imam Hanafi bisa kita ketahui dengan baik. Dia menulis tiga kitab yang sangat pakat bahwa muslim-kafir tidak saling mewarisi. Berbeda halnya bila mereka sama-sama kafir, mereka bisa saling mewarisi; seperti Yahudi dapat mewarisi Kristiani atau sebaliknya. Inilah pendapat $\mathrm{Abu}$ Hanifah dan mayoritas ulama kami". Pendapat ini mereka bangun atas dasar hadits berikut: "La yarits al-muslimu al-kafira, wa la al-kafiru al-muslima" (Seorang muslim tidak menjadi pewaris dari orang kafir, demikian pula orang kafir tidak menjadi pewaris dari orang Islam). ${ }^{27}$

Dengan dasar hadits yang sama, Imam Malik juga mengemukakan pendapat yang sama. Bahkan untuk menegaskannya dia menambahkan riwayat dari Ibn Syihab dan Ali ibn Husein ibn Ali ibn Abi Thalib yang menerangkan bahwa 'Aqil dan Thalib mewarisi harta Abu Thalib sementara Ali yang juga putra Abu Thalib tidak menjadi pewarisnya. ${ }^{28}$ Riwayat ini menunjukkan bahwa ketika Abu Thalib meninggal dunia, dia masih dalam keadaan tidak Islam sehingga Ali yang sudah masuk Islam tidak dapat mewarisi harta peninggalan Abu Thalib.

Imam Bukhari juga berpendirian sama. Namun selain mencantumkan hadits yang sama dengan Imam Malik dan al-Syaibani, ada catatan menarik dari Imam Bukhari ketika dia mencantumkan judul "bab la yarits al-muslim al-kafira wala al-kafir al-muslima, wa idza aslama qabla an yuqassam almirats fala miratsa lahu". 29 pencantuman judul bab itu mengindikasikan bahwa menurut Imam Bukhari seorang kafir yang baru masuk Islam sebelum harta warisan dibagikan tetap tidak berhak mendapatkan bagian warisan.

Pendapat Imam Bukhari itu berbeda dengan pendapat Imam Syafii yang menyatakan bahwa seorang muslim bisa menjadi pewaris orang kafir, akan tetapi

populer, yaitu al-Muwattha', al-Jami' al-Shaghir dan Kitab al-Ashl.

27 Muhammad Ibn al-Hasan al-Syaibani, alMuwattha' (Beirut: al-Maktabah al-'Ilmiah, t.t), h. 255.

28 Imam Malik, al-Muwattha' (Juz II; Beirut: Dar Ihya’ al-`Ulum, 1990), h. 59.

29 Imam Bukhari, Shahih Bukhari (Juz IV; Indonesia:Фan thyaval-Kutub al-'Arabiah, t.t), h. 170. 
orang kafir tidak bisa menjadi pewaris seorang muslim. Pendapat Imam Syafii ini didasarkan pada riwayat Mu'adz ibn Jabal, Mu'awiyah (dari kalangan sahabat), Masruq, Ibn al-Musayyib dan Muhammad ibn 'Ali ibn Husein (dari kalangan tabi'in). Namun, sayang sekali Imam Syafii tidak mencantumkan jalur sanad hadits tersebut secara sempurna. Dalam Sunan Sa'id ibn Manshur dinyatakan bahwa pendapat itu hanyalah hasil ijtihad sahabat, khususnya Mu'awiyah. ${ }^{30}$

Mayoritas sahabat dan tabi'in serta para fuqaha, kata Ibnu Rusyd, sepakat bahwa muslim-kafir tidak saling mewarisi. Sementara Mu'adz ibn Jabal dan Mu'awiyah dari kalangan sahabat serta Ibn al-Musayyab dan Masruq dari kalangan tabi'in membolehkan muslim mewarisi kafir, tapi tidak sebaliknya. Mereka menyamakan kasus itu dengan para wanita ahl al-kitab yang boleh dinikahi, demikian pula halnya dengan system waris. Untuk itu mereka juga mengemukakan dasar hadits meski kemudian terbukti hadits mengenai hal itu ternyata tidak kuat. ${ }^{31}$

Data tersebut semakin memperkuat pendapat bahwa kebolehan seorang muslim mewarisi orang kafir hanyalah hasil ijtihad sebagian sahabat Nabi. Dengan demikian wajar bila Imam Bukhari tidak mengelaborasi versi hadits seperti itu.

\section{Mencium istri dan menyentuh kemaluan setelah berwudu'}

Apakah orang harus berwudu' kembali jika dia mencium (qabbala) istrinya? Imam Malik (dengan tiga buah hadits) dan Imam Syafii (dua buah hadits) sepakat bahwa mencium istri menyebabkan "batal" wudu'. Berbeda dengan kedua tokoh ini, Imam Ahmad ibn Hanbal justru menampilkan versi hadits lain yang menerangkan bahwa: “Nabi mencium istrinya kemudian dia me-

30 Imam Syafii, al-Umm (JUz IV; Beirut: Dar alFikr, 1983), h. 93-94; Sa'id ibn Manshur, Sunan Sa'id ibn Manshur (Beirut: Dar al-Kutub al-'Ilmiah, t.t), h. 65-68.

31 Ibnu Rusyd, Bidayah al-Mujtahid (Juz II; Indonesia: Syirkah Nur Asia, t.t), h. 264. lakukan shalat dan tidak berwudu' lagi"'.32

Adapun pendapat Imam Malik dan Imam Sayfii mengenai masalah menyentuh kemaluan setelah berwudu', sama dengan pandangan mengenai suami yang mencium istrinya setelah berwudu'. Pendapat serupa juga dikemukakan pula oleh Imam Ahmad ibn Hanbal. Sementara itu, al-Syaibani menyatakan bahwa menyentuh (massa) kemaluan tidak membatalkan wudu'. Bahkan untuk menguatkan pendapatnya, dalam kitab al-Muwattha', al-Syaibani mencantumkan 16 buah hadits. Pendapat ini sama dengan pandangan gurunya, Imam Hanafi. ${ }^{33}$

Kedua masalah tersebut tidak sedikitpun disinggung oleh Imam Bukhari. Padahal dalam kasus mencium istri, beberapa murid Imam Bukhari seperti Abu Daud (w. 275 H), al-Turmudzi (w. $279 \mathrm{H}$ ), al-Nasai (w. $303 \mathrm{H}$ ) dan Ibnu Majah (w. 279 H) juga memasukkan hadits-hadits yang sama dengan Imam Malik dan Imam Syafii. Apakah hadit-hadits itu asing bagi Imam Bukhari ? Dengan melihat jalur sanad yang terdapat dalam hadits-hadits yang dikemukakan Imam Malik dan Imam Syafii, sangat tidak mungkin Imam Bukhari tidak mengenal figur-figur tersebut. Sebab rawi-rawi yang ada dalam sanad itu juga sering digunakan Imam Bukhari. Apalagi Imam Ahmad ibn Hanbal, salah seorang guru Imam Bukhari, jugameriwayatkanhaditsyangsamadengan hadits Imam Malik dan Imam Syafii. Imam Ahmad ibn Hanbal juga mencantumkan riwayat lain yang menjelaskan bahwa menyentuh kemaluan tidak membatalkan wudu'; karena: "kemaluan itu tidak lebih dari bagian anggota tubuh yang lain (innama huwa bud'atun minka au jasadika).

Mengapa Imam Bukhari tidak mengelaborasi hadits-hadits yang berkenaan dengan dua masalah itu? Ada dua kemungkinan

32 Imam Syafii, Musnad al-Imam al-Syafii (Beirut: Dar al-Kutub al-'Ilmiah, t.t), h. 12-13; Ahmad ibn Hanbal, Musnad Ahmad ibn Hanbal (Juz V; Beirut: Dar al-Fikr, t.t), h. 244-246.

33 Imam Syafii,. al-Umm., h. 12-13, lihat juga Imam Syafii, Musnad., h. 12-13. h. 35-38; lihat juga alSyaibani, Kitab al-Ashl al-Ma'ruf bi al-Mabsuth (Juz I; Beirut: 'A4ante dl-Kkthtub, 1990), h. 64. 
alasan yang dapat dikemukakan untuk menjawabnya. Pertama, Imam Bukhari sengaja tidak memasukkan hadits itu ke dalam kitabnya. Sebab dia pernah berkata: "Saya tidak memasukkan ke dalam kitab al-Jami' al-Shahih ini selain hadits-hadits shahih; dan kutinggalkan banyak hadits shahih karena khawatir membosankan". ${ }^{34}$ Namun alasan ini rasanya kurang tepat sebab dalam kasus yang lain Imam Bukhari justru melakukannya dengan panjang lebar. Misalnya tentang lailah al-qadar; dia mencantumkan 14 buah hadits yang sangat variatif dan panjang. ${ }^{35} \mathrm{Kedua}$, Imam Bukhari merasa "tidak perlu" lagi mencantumkan hadits-hadits itu karena dia terlebih dahulu mencantumkan sebuah judul: "Bab man lam yara al-wudu' illa min al-mukhrojain min alqubuli wa al-duburi (bab tidak perlunya melakukan wudu' kecuali karena adanya sesuatu yang keluar dari qubul dan dubur)". Selain itu, Imam Bukhari juga mengutip pendapat tabi'in seperti 'Atha', Thawus, Muhammad ibn 'Ali dan ulama Hijaz serta pendapat-pendapat sahabat seperti $\mathrm{Abu}$ Hurairah, al-Hasan, Abdullah Ibn Umar dan Jabir ibn Abdillah yang intinya "tidak perlu melakukan wudu' kecuali kalau terjadi hadats". ${ }^{36}$

Kemudian, ketika membahas penafsiran terhadap ayat-ayat al-Quran, tepatnya Surat al-Maidah: 7 (au lamastum al-nisa), Imam Bukhari hanya mencantumkan penafsiran Ibnu Abbas yang menerangkan bahwa pengertian lamastum, al-ifda', tamassuhunna dan wa allati dakhaltum bihinna adalah al-nikah (hubungan suami istri). ${ }^{37}$

Menurut saya, alasan kedua ini lebih rasional. Artinya dengan indikator: (1) tidak dicantumkannya hadits tentang mencium istri dan menyentuh kemaluan, (2) pencan-

34 Abu Syuhbah, Fi Rihab al-Sunnah al-Kutub al-Sittah (Kairo: Majma' al-Buhuts al-Islamiah, 1979), h. 94.

35 Mengani masalah ini telah saya lakukan dalam bentuk penelitian tersendiri. Untuk lebih detail lihat Abdul Sattar, Telaah Hadits-Hadits Lailah al-Qadar Dalam Shahih Bukhari (Semarang: Pusat Penelitian IAIN Walisongo, 1999).

36 Imam Bukhari, al-Jami'., h. 44-45.

37 Imam Bukhari, al-Jami',,h. 123. tuman judul bab, pendapat sahabat dan tabi'in serta (3) pemilihan penafsiran Ibnu Abbas, sebenarnya Imam Bukhari secara tidak langsung ingin mengatakan bahwa mencium istri dan menyentuh kemaluan tidak membatalkan wudu'. Bukti ini semakin memperjelas status Imam Bukhari sebagi seorang faqih yang independen.

\section{Jumlah rakaat shalat tarawih (qiyam al-lail)}

Dengan mendasarkan pendapatnya kepada riwayat Umaribn Khattab, Imam Syafii mengatakan: "Saya lebih suka melakukan shalat tarawih 23 rakaat, yaitu 20 rakaat tarawih dan 3 rakaat witir. Penjelasan serupa juga dikemukakan Imam Malik dari Yazid ibn Ruman (w. 130 H). Pada masa Umar ibn Khattab orang-orang melakukan shalat tarawih sekaligus witir sebanyak 23 rakaat. Namun, perlu juga dicatat bahwa Imam Malik juga mencantumkan riwayat yang menjelaskan bahwa Umar menyuruh Ubay Ka'ab dan Tamim al-Dari untuk melakukan shalat malam sebanyak 11 rakaat. Bahkan lebih dari itu, Imam Malik menampilkan 3 hadits muttashil yang menerangkan praktek shalat Nabi sebanyak 11 rakaat..$^{38}$ Persoalannya adalah mengapa Imam Malik kemudian juga menegaskan bahwa jumlah shalat btarawih itu 20 rakaat plus 3 rakaat witir? Hal ini sepenuhnya dapat dimengerti bila kita melihat Imam Malik sebagai ulama Madinah yang menjadikan amal penduduk Madinah menjadi salah satu sumber hukum dalam Islam.

Sementara itu, Imam Bukhari juga secara panjang lebar mencantumkan cerita tentang respon Umar terhadap praktek sahabat Madinah yang mengerjakan shalat tarawih secara sendiri-sendiri. Ketika melihat itu, Umar berinisiatif untuk menyatukan para sahabat agar mau melakukan shalat tarawih secara berjamaah dibawah satu imam (saat itu diusulkan nama sahabat Ubay ibn Ka'ab sebagai imam). Para sahabat ternyata setuju sehingga pada hari-hari berikutnya mereka

38 Imam Syafii, al-Umm., h. 167; Imam Malik, al-Jami'., h 138 \& $\&$ d 41 it 43 . 
menjalankan tarawih secara berjamaah.

Yang menarik, meski mengemukakan cerita tentang penyatuan shalat tarawih secara berjamaah, Imam Bukhari tidak mengetengahkan jumlah rakaat yang disarankan Umar sekaligus dijalankan para sahabat saat itu. Dia justru menampilkan kurang lebih 17 buah hadits (semuanya riwayat Aisyah) yang menginformasikan praktek shalat malam Nabi yang tidak lebih dari 11 rakaat baik di dalam maupun diluar Ramadan. ${ }^{39}$ tampa sedikit pun mengelaborasi keterangan mengenaijumlah rakaat shalat malam 23 rakaat (bahkan menjadi 39 rakaat pada masa Umar ibn Abdul Aziz), Imam Bukhari ingin menjelaskan dua hal. Pertama, jumlah rakaat shalat malam adalah 11 rakaat (8 rakaat tarawih dan 3 rakaat witir), tidak lebih. Kedua, penentuan jumlah rakaat menjadi 23 rakaat sama sekali tidak didasarkan pada sunnah yang diwariskan Nabi. Penentuan jumlah itu "hanya" berdasarkan pada ijtihad Umar.

Perlu dikemukakan disini bahwa salah satu hadits yang menerangkan shalat tarawih 20 rakaat hanya diriwayatkan oleh al-Baihaqi. Hadits tersebut adalah: "Kana al-Nabi Saw yushalli fi syahri Ramadan fi ghairi jama'atin bi 'isyrina rak'atan wa al-witr" (Nabi Saw mengerjakan shalat pada bulan Ramadan tanpa berjamaah sebanyak 20 rakaat plus witir). ${ }^{40}$

Berkenaan dengan hadits tersebut, ada komentar menarik dari al-Baihaqi sendiri yang menerangkan bahwa Abu Syaibah (salah satu rawi dalam hadits tersebut) terkenal sebagai rawi yang lemah. Bahkan komentar lebih keras muncul dari ulama hadits kontemporer, Nashral-Din al-Albani. Menurutal-Albani, haditsinimaudu' karena tiga sebab utama. Pertama, Abu Syaibah dikenal sebagai rawi yang lemah. Kedua, materi (matan) hadits bertentangan dengan hadits shahih lain dari riwayat-riwayat Aisyah. Ketiga, materi hadits menjelaskan shalat Nabi tanpa jamaah, padahal dalam

\footnotetext{
39 Imam Bukhari, al-Jami',., h. 197-199 \& 343-344.

40 Imam al-Baihaqi, al-Sunan al-Kubra (Beirut: Dar al-Fikr, t.t), h. 396.
}

riwayat Jabir dan Aisyah dijelaskan bahwa nabi shalat secara berjamaah (periksa yang tertuang dalam footnote no. 41$){ }^{41}$

\section{Kesimpulan}

Dari uraian tersebut, dapat kemukakan beberapa simpulan sebagai berikut; Pertama, Selain ahli hadits, Imam Bukhari juga ahli fiqh. Kedua, Pengelompokan Imam Bukhari ke dalam kelompok tertentu (seperti Syafiaah maupun yang lainnya) hanya tepat bila didasarkan pada jalur keguruan belaka, bukan pada produk pemikiran. $\mathrm{Ke}$ tiga, Corak dan konstruk Imam Bukhari dibangun atas tiga hal, yaitu:pemilihan hadits, pencantuman judul bab dan pemilihan pendapat sahabat maupun tabi'in. Keempat, Hadits-hadits yang dimuat Imam Bukhari dalam al-Jami al-Shahih dilakukan bukan atas dasar pemihakannya terhadap ulama fiqh tertentu, tetapi didasarkan atas kualifikasi atau syarat-syarat penerimaan hadits shahih yang telah dia tetapkan. Kelima, Bila terdapat banyak hadits yang membicarakan sebuah topik tertentu, Imam Bukhari menempuh langkah sebagai berikut, a) mengenyampingkan hadits shahih bila terdapat banyak hadits lain yang juga berkualitas shahih sementara matan haditsnya berbeda dengan riwayat shahih kebanyakan. Hal ini bisa dilihat dalam kasus bacaan basmalah dalam shalat. b) mengutamakan hadits musnad daripada hadits mauquf meskipun ia berada pada jalur mata rantai emas (silsilah al-dzahab) seperti kasus mengusap tangan dalam tayammum. c) bila terjadi perbedaan antara tradisi Nabi dengan sahabat, Imam Bukhari lebih mengutamakan tradisi Nabi daripada pendapat atau ijtihad sahabat. Hal ini bisa dilihat dalam kasus shalat tarawih dan sistem warisan muslim-kafir. Keenam, AlJami' al-Shahih ternyata tidak hanya berisi hadits-hadits Nabi saja, tetapi juga membuat pendapat-pendapat sahabat dan tabi'in. Wallahu a'lam bi al-shawab.

$41 \quad$ Nashr al-Din al-Albani, Silsilah al-Ahadits alDai'ifah wa al-maudu'ah (Jilid II; Saudi Arabia: Lajnah Ihya' al-Sunnaha 1399 H), h. 35-36. 


\section{DAFTAR PUSTAKA}

'Abd al-Hay, Abu al-Falah. t.t. Syadzrat alDzahab fi Akhbar man Dzahab. Beirut: Dar al-Kutub al-'Ilmiah.

'Ithr, Nur al-Din. 1401 H. Manhaj al-Naqd fi 'Ulum al-Hadits. Beirut: Dar al-Fikr.

Abi Ya'la, Ibnu. t.t. Thabaqat al-Hanibalah. Beirut: Dar al-Ma'arif.

Ahmad, Imam. t.t. Musanad Ahmad ibn Hanbal. Beirut: Dar al-Fikr.

Al-Albani, Nasr al-Din. 1399. Silsilah al-Ahadits al-Dai'ifah wa al-maudu'ah. Saudi Arabia: Lajnah Ihya' al-Sunnah.

Al-Asnawi, 'Abd al-Rahim. 1987. Thabaqat al-Syafiiah. Beirut: Dar al-Kutub al'Ilmiah.

Al-Baihaqi, Imam. t.t. al-Sunan al-Kubra. Beirut: Dar al-Fikr.

Brockelmann, Carl. 1987. E.J Brill's Encyclopedia of Islam 1913-1936, ed. M.Th. Houstma et.all Leiden: E.J Brill.

Bukhari,Imam. t.t. al-Jami'al-Shahih. Indonesia: Dar Ihya al-Kutub al-'Arabiyah.

Al-Dimasyqi, Taqiyuddin Ibnu Qadi Syuhbah (selanjutnya disebut al-Dimasyqi), t.t. Thabaqat al-Syafi'iah. Beirut: Dar al-Fikr.

Al-Dzahabi. t.t. Tadzkirah al-Huffadh. Beirut: Dar al-Kutub al-'Ilmiah.

Gibb, H.A.R, dan J.H Kramers. 1961. Shorter Encyclopedia of Islam. Leiden: E.J Brill.

Hajar, Ibnu. t.t. Hadi al-Sari. Riyad: Risalah Idarat al-Buhuts al-'Ilmiah wa al-Ifta' wa al-Da' wah wa al-Irsyad.

........... t.t. Muqaddimah Fath al-Bari. Beirut: Dar al-Fikr.

.1994. Tahdzib al-Tahdzib. Beirut: Dar al-Kutub al-'Ilmiah.

Hasyim, Al-Husaini 'Abd al-Majid1996. alImam al-Bukhari: Muhaddits wa Faqih.
Kairo: Dar al-Qaumiah li al-Thiba'ah wa al-Nasyr.

J.Robson. 1960. The Encyclopedia of Islam. ed. H.A.R Gibb et.all. Leiden: E.J Brill.

Malik, Imam. 1990. al-Muwattha'. Beirut: Dar Thya al-'Ulum.

Manshur, Sa'id ibn. t.t. Sunan Sa'id ibn Manshur. Beirut: Dar al-Kutub al-'Ilmiah.

Nasution, Harun, et.all (Tim Penyusun). 1992. Ensiklopedi Islam Indonesia. Jakarta: Djambatan.

Al-Nawawi. 1402 H. Syarh Muslim. Beirut: Dar al-Fikr.

Rusyd, Ibnu. t.t. Bidayah al-Mujtahid. Indonesia: Syirkah Nur Asia.

Sattar, Abdul. 1999. Telaah Hadits-Hadits Lailah al-Qadar Dalam Shahih Bukhari. Semarang: Pusat Penelitian IAIN Walisongo.

Speight, R. Marston.1993. The Encyclopedia of Religion, ed. Micea Eliade. London: Collier Macmillan Publishers.

Al-Suyuthi, Jalal a-Din. 1392 H. Tadrib alRawi, ed. Abd al-Wahab 'Abd al-Latif. Madinah: al-Maktabah al-'Ilmiah.

Syafii, Imam. 1983. al-Umm. Beirut: Dar alFikr.

...1985. Ikhtilaf al-Hadits. Beirut: Muassasah al-Kutub al-Tsaqafiah.

t.t. Musnad al-Imam al-Syafii. Beirut: Dar al-Kutub al-'Ilmiah.

Al-Syaibani, Muhammad Ibn al-Hasan. t.t. al-Muwattha'. Beirut: al-Maktabah al'Ilmiah.

1990. Kitab al-Ashl al-Ma'ruf bi alMabsuth. Beirut: 'Alam al-Kutub.

Syuhbah, Muhammad Muhammad Abu. 1979. Fi Rihab al-Sunnah al-Kutub alShihah al-Sittah. Kairo: Majma' alBuhuts al-Islamiah. 